\title{
PERANCANGAN TATA LETAK DAN FASILITAS HUNIAN RUKOST BERDASARKAN KEBUTUHAN KONSUMEN UNTUK MENINGKATKAN PANGSA PASAR DENGAN MENGGUNAKAN ASPEK ERGONOMI
}

\author{
Leola Dewiyani, M. Kosasih \\ Program Studi Teknik Industri, Fakultas Teknik \\ Universitas Muhammadiyah Jakarta \\ leoladewiyani@gmail.com
}

\begin{abstract}
Abstrak
Saat ini Karawang dikenal sebagai daerah industri yang paling berpotensi di wilayah Jawa Barat. Hal tersebut dibuktikan dengan banyaknya pabrik yang didirikan di tanah Pasundan ini. Dengan banyaknya usaha baik berupa pabrik maupun yang lainnya, Karawang menjanjikan aneka macam peluang di berbagai bidang usaha yang bisa mendatangkan keuntungan. Perusahaan ini tentu membutuhkan tenaga kerja yang cukup banyak, tidak hanya buruh lebih dari itu tenaga kerja yang dibutuhkan juga berasal dari level menengah ke atas hingga staf profesional, hal ini yang menjadi daya tarik bagi pengembang untuk membangun bisnis properti di Karawang yaitu RuKost (rumah kos). Akan tetapi Tata Letak interior kamar yang ada di RuKost saat ini berdasarkan penelitian pendahuluan yang dilakukan peneliti belum memenuhi standar dan juga belum memperhatikan kenyamanan, kepuasan, keselamatan dan kesehatan karena desain layout interior yang ada pada kamar RuKost saat ini kurang memperhatikan prinsip-prinsip ergonomik. Berdasarkan kondisi di atas maka akan dilakukan suatu redesign terhadap tata letak interior kamar RuKost. Metode perancangan yang akan digunakan dalam penelitian ini adalah antropometri dan physiological performance.
\end{abstract}

Kata kunci: Layout, antropometri, physiological performance

\section{PENDAHULUAN}

A. Latar Belakang Masalah

Karawang merupakan salah satu kota di Indonesia yang terletak di propinsi Jawa Barat yang dulunya dikenal sebagai daerah pertanian atau lumbung padi nasional. Seiring dengan berjalannya waktu saat ini Karawang dikenal sebagai daerah industry yang paling berpotensi di wilayah Jawa Barat. Hal tersebut dibuktikan dengan banyaknya pabrik yang didirikan di tanah Pasundan ini. Dengan banyaknya usaha baik berupa pabrik maupun yang lainnya, Karawang menjanjikan aneka macam peluang di berbagai bidang usaha yang bisa mendatangkan keuntungan. Dengan diterapkannya kebijakan AFTA maka kawasan industri Karawang mulai banyak diisi oleh perusahaan mapan, baik dari dalam negeri maupun multinasional. Associate Director Research Colliers International Indonesia Ferry Salanto mengatakan bahwa potensi pengembangan kawasan ini ke depannya terus berlangsung mengingat jumlah lahannya yang cukup besar, oleh karena itu saat ini perusahaan asing makin memenuhi kawasan industri Karawang antara lain perusahaan Jepang, Korea dan Cina. Perusahaan-perusahaan ini tentu membutuhkan tenaga kerja yang cukup banyak, tidak hanya buruh lebih dari itu tenaga kerja yang dibutuhkan juga berasal dari level menengah ke atas hingga staf professional, hal ini yang menjadi daya tarik bagi pengembang untuk membangun bisnis properti di Karawang. Jika melihat keseharian pekerja profesional yang tinggal di Jakarta dan bekerja di Karawang maka akan sulit untuk menyesuaikan waktunya karena saat ini tidak ada jam-jam kosong di jalan tol sepanjang Jakarta-Karawang-Bandung. Kondisi jalan tol dari Jakarta ke Karawang atau sebaliknya, sering mengalami kemacetan yang bersifat un-predictable tidak hanya pada jam-jam tertentu. Melihat potensi dan populasi yang terus bertambah, menarik pengembang untuk mengembangkan kawasan residensial di daerah Karawang. Salah satu properti yang inovatif adalah RuKost (rumah kost) Columbus yang dibangun dengan konsep rumah kost yang terbilang baru di industri properti, khususnya di Karawang. RuKost adalah pionir pengembangan properti yang sangat mengesankan bagi para investor semenjak awal pembangunannya di tahun 2015. Market produk terbaru ini cukup luas, target penyewa adalah 
segment pasar kelas menengah atas yang berasal dari wilayah industri terbesar di Karawang Barat yaitu karyawan yang saat ini mencapai ribuan, para dokter dan mahasiswa/mahasiswi yang memiliki potensi sangat baik. Berdasarkan studi pendahuluan yang dilakukan oleh Leola Dewiyani (2016) bahwa hunian kos-kosan di daerah Karawang terbilang banyak akan tetapi yang memenuhi keinginan konsumen terutama dari segmen pasar kelas menengah atas belum ada, berdasarkan kuesioner yang disebar bahwa yang mereka butuhkan adalah hunian yang layaknya hotel yaitu letaknya strategis, nyaman, indah dan ergonomis (mengandung unsur kesehatan dan keselamatan). Dari segi lokasi RuKost Columbus adalah lokasi yang strategis karena terletak di pusat kota Karawang dan ditunjang pula dengan bangunan yang kokoh dan modern yang berbeda dari bangunan kos pada umumnya di Karawang, namun kendalanya adalah ukuran kamar yang tergolong kecil yang hanya mempunyai luas total $9 \mathrm{~m}^{2}$ (termasuk kamar mandi di tiap kamarnya) sehingga ruang gerak penghuni menjadi terbatas. Tata Letak interior kamar yang ada di RuKost saat ini umumnya belum memenuhi standar dan juga belum memperhatikan kenyamanan, kepuasan, keselamatan dan kesehatan karena desain layout interior yang ada pada kamar RuKost saat ini kurang memperhatikan prinsip-prinsip ergonomi. Hal ini tentunya akan sangat berpengaruh kepada kualitas istirahat penghuni RuKost yang pada akhirnya juga akan mempengaruhi produktivitas dimana mereka bekerja keesokan harinya. Berdasarkan latar belakang tersebut maka peneliti akan melakukan penelitian dengan judul "Perancangan Tata Letak dan Fasilitas Hunian RuKost Berdasarkan Kebutuhan Konsumen Untuk Meningkatkan Pangsa Pasar Dengan Menggunakan Aspek Ergonomi”

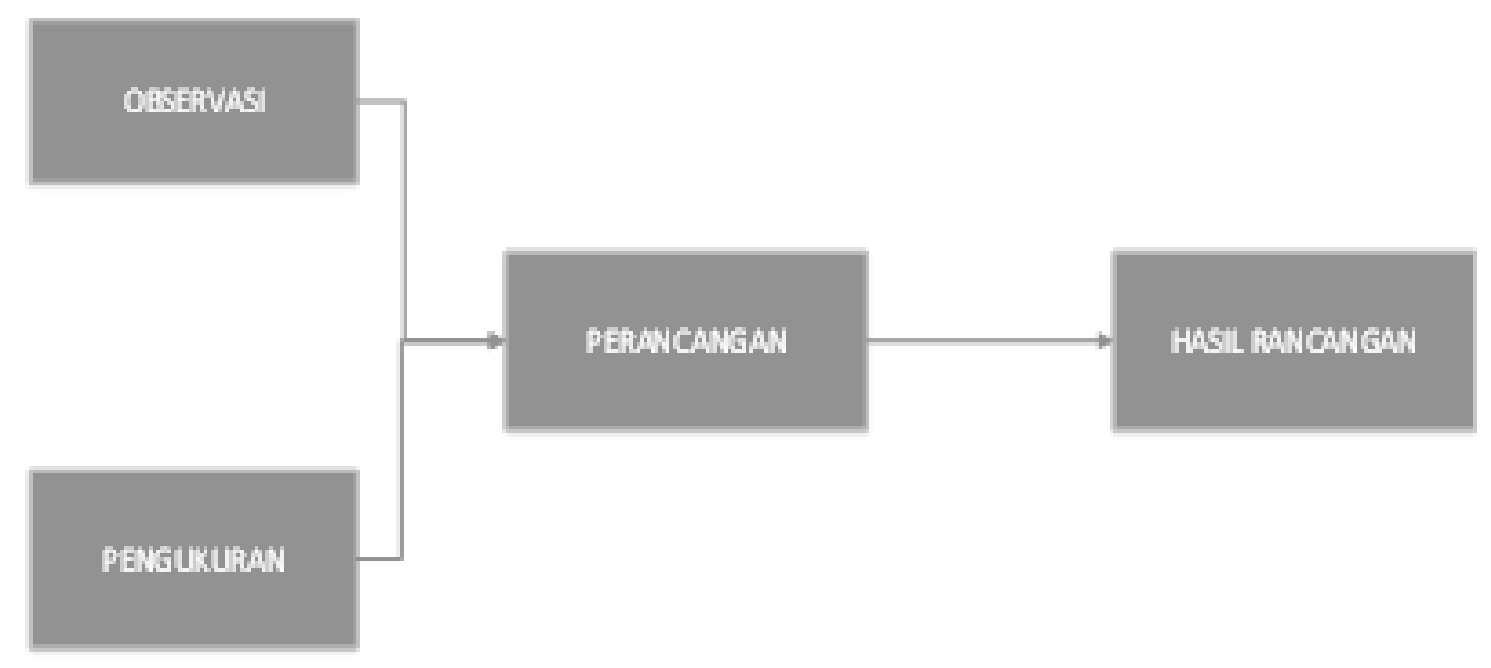

Gambar 1. Kerangka Konsep Perancangan RuKost

Perancangan merupakan proses yang bertujuan untuk memperbaiki dan menyusun suatu system, baik system fisik maupun non fisik untuk waktu yang akan dating dengan memanfaatkan informasi yang ada. Tentunya informasi yang akurat memegang peranan yang penting guna menghasilkan perancangan yang baik. Urutan proses yang dilakukan dalam penelitian ini adalah seperti terlihat pada gambar 1 .

\section{B. Desain Tata Letak Fasilitas Kamar Rukost}

Dengan dinobatkannya Karawang sebagai kawasan industri terbesar di Asia Tenggara maka seiring dengan hal tersebut saat ini berkembang pula bisnis properti dalam hai ini RuKost. Akan tetapi RuKost yang ada saat ini berdasarkan penelitian pendahuluan yang dilakukan peneliti belum memenuhi standar dan kriteria hunian yang diinginkan pelanggan kelas menengah atas. Kategori karyawan menengah atas dalam peneltian ini adalah minimal menduduki jabatan 
middle management, expert baik yang berasal dari dalam dan luar negeri, para dokter dan pengusaha. Padahal peluang pelanggan kelas ini sangat potensial. Selama ini mereka menginap di hotel disekitar karawang yang tentunya hal ini akan menyebabkan pembiayaan yang membengkak bagi perusahaan tempat mereka bekerja maupun secara pribadi. Mengingat makin banyaknya pendatang yang bekerja di Karawang dan semakin banyak customer yang demanding maka penting untuk melakukan desain yang dapat mengembangkan usaha RuKost yang profesional sesuai dengan tuntutan masyarakat.

\section{LANDASAN TEORI}

\section{A. Pengertian Desain}

Desain merupakan istilah yang berasal dari kata design yang berarti gambar. Dan pada abad 17 kata design tersebut mempunyai makna baru yaitu craft, selanjutnya oleh Ruskin Morris kata desain dimaknai sebagai art and craft yang merupakan paduan seni dan ketrampilan. Ada beberapa aspek yang harus diperhatikan dalam mendesain suatu ruang. Berikut ini adalah pendapat beberapa ahli mengenai aspek desain antara lain Prasetyawibowo (1998) yang menjelaskan bahwa ada 6 aspek dari desain yang perlu diperhatikan yaitu: aspek fungsional, aspek teknik, aspek ergonomi, aspek ekonomi, aspek sosial budaya dan aspek visual. Selanjutnya Ppada tahun 1999 Palgunadi menjelaskan bahwa aspek desain yang perlu diperhatikan dalam perancangan adalah aspek pengguna, aspek afungsi dan spek ergonomi. Sebenarnya dari kedua pendapat tersebut di atas tidak ada perbedaan yang mendasar tentang aspek desain dimana beberapa aspek dapat mempunyai peran yang bersifat dominan atau bahkan sama sekali tidak dominan karena besar kecilnya peran suatu aspek desain tertentu sangat bergantung pada produk yang akan dirancang.

\section{B. Tata Letak Ruang}

Ruang atau ruangan diartikan sebagai suatu area dimana manusia dapat menghabiskan sebagian besar waktunya untuk melakukan berbagai kegiatan yaitu bekerja, belajar, santai dan beristirahat, kumpul keluarga dan lain-lain. Berbicara tentang ruang dikenal istilah ruang dalam/interior yaitu suatu ruang yang tercipta dari struktur dan rangka bangunan dengan batasan solid/padat, dimana didalamnya harus dapat memberikan suasana nyaman, tentram dan sehat sehingga penghuninya dapat beristirahat dan melakukan kegiatan refreshing sehabis pulang dari melakukan aktifitas pekerjaan yang padat pada siang harinya. Agar dapat memfasilitasi dengan optimal kebutuhan penghuninya maka diperlukan desain interior dan tata letak yang tepat guna terbentukmnya kesatuan unsur fungsi, daya tahan serta keindahan di dalamnya yaitu melalui elemen titik, garis, bidang serta volume yang diatur sehingga memberikan bentuk pada bangunan dan menjadi pembeda antara luar dan dalam, serta menjadi batasan bagi ruang interior. Batas ruang umumnya berbentuk langit-langit, dinding dan lantai. Ventilasi, jendela dan pintu merupakan akses yang menghubungkan ruang luar dan ruang bagian dalam. Ukuran, skala dan proporsi akan membentuk karakter dari suatu ruang interior (Francis D.K Ching)

\section{Konsep Ergonomi}

Ergonomi merupakan ilmu intersisipliner yang merancang peralatan dan tugas untuk mengoptimalkan kapasitas manusia, merupakan desain yang mengharmonikan hubungan antara kemampuan dan batasan manusia dengan sistim (Macleod, 2000). Studi ergonomi merupakan studi yang mempelajari interaksi antara 3 aspek resiko yaitu:

a. Faktor resiko yang melekat pada pekerjaan

b. Faktor resiko yang melekat pada alat yang digunakan ketika bekerja

c. Faktor resiko yang melekat pada lingkungan kerja

Manusia sebagai individu tentunya mempunyai limitasi dan kapasitas yang menjadi sentral dari 3 aspek resiko di atas sehingga muncul prinsip fit the to the person, not the person to the task, artinya bahwa dalam mendesain suatu sistim kerja termasuk ruang kamar RuKost tetap 
harus mempertimbangkan berbagai faktor yang dapat berpengaruh pada manusia baik dari segi anatomi, fisik dan psikologi.

Sistem yang baik hanya dapat dicapai bila dalam sistem tersebut terdapat:

a. Elemen sistem yang telah dirancang sesuai dengan yang dibutuhkan

b. Elemen sistem saling berinteraksi dalam mencapai tujuan

\section{Antropometri}

Menurut Sritomo Wignjosoebroto antropometri berasal dari kata "anthro" yang berarti manusia dan " metri " yang berarti ukuran. Antropometri diartikan sebagai suatu studi yang berkaitan dengan pengukuran berbagai dimensi tubuh manusia. Data antropometri digolongkan menjadi 2 yaitu:

a. Ukuran statis, merupakan ukuran yang berkaitan dengan struktur tubuh yang meliputi kepala, dada dan anggota tubuh dalam posisi diam

b. Ukuran dinamis, merupakan ukuran anggota tubuh berkaitan dengan fungsional tubuh yang meliputi semua anggota tubuh dalam posisi melakukan suatu gerakan tertentu.

Seperti kita ketahui pada dasarnya setiap manusia mempunyai ukuran (tinggi, lebar, berat.) dan bentuk yang unik yang berbeda antara satu dengan yang lainnya. Olehkarenanya antropometri digunakan dalam proses perancangan (desain) produk yang nantinya digunakan sebagai dasar pertimbangan-pertimbangan ergonomis dalam produk yang dihasilkan. Data antropometri tersebut selanjutnya akan diaplikasikan secara luas antara lain dalam hal :

- Perancangan areal kerja

- Perancangan peralatan kerja

- Perancangan produk-produk konsumtif

- Perancangan lingkungan kerja fisik

Selanjutnya untuk memperjelas mengenai data antropometri untuk bisa diaplikasikan dalam berbagai rancangan produk ataupun fasilitas kerja menurut Eko Nurmianto dalam bukunya, maka pada gambar 2 dibawah ini memberikan informasi tentang berbagai macam anggota tubuh yang perlu diukur.
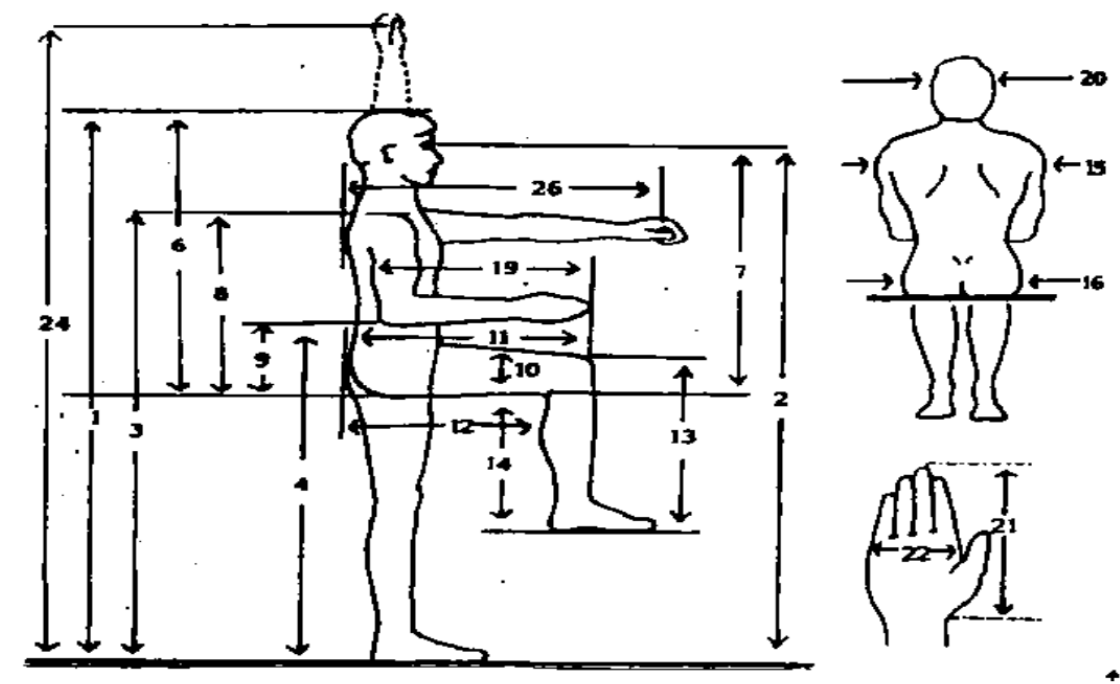

Gambar 2. Antropometri Tubuh Manusia yang Diukur Dimensinya 


\section{METODOLOGI PENELITIAN}

\section{A. Pengumpulan Data}

Ada dua macam data yang dikumpulkan yaitu:

1. Pengumpulan data untuk melakukan identifikasi faktor-faktor yang dibutuhkan dalam pemilihan RuKost maka dilakukan pengambilan data pada penelitian ini adalah secara kuantitatif dan kualitatif. Data kuantitatif diperoleh melalui melalui penyebaran kuesioner yang dibutuhkan untuk memperoleh kecenderungan perilaku dan kebutuhan serta keinginan user dalam hal ini penghuni RuKost secara representatif. Konsep kuesioner ini adalah untuk mengetahui hal-hal yang berkaitan dengan karakteristik target penghuni RuKost.

2. Pengumpulan data berikutnya adalah untuk melakukan identifikasi yang berkaitan dengan desain kamar RuKost. Pengumpulan data dilakukan secara langsung pada stasiun kerja ( selanjutnya disebut kamar RuKost) untuk mengetahui kondisi kamar. Dalam pengamatan ini dilakukan pengambilan gambar terhadap kamar RuKost,pengambilan/pengumpulan ukuran Kamar RuKost kerja, dimensi tubuh manusia. Selanjutnya data antropometri akan diolah menjadi tabel antropometri yang nantinya digunakan untuk analisa antropometri tentang perancangan fasilitas pada Kamar RuKost.

\section{B. Pengolahan Data}

Data-data yang telah didapatkan, selanjutnya akan diolah sebagai berikut :

a. Data dimensi tubuh manusia selanjutnya akan analisis statistik yang diperlukan dalam pengolahan data ini adalah uji kenormalan data, uji keseragaman, uji kecukupan data, selanjutnya akan dihitung percentile untuk masing-masing dimensi tubuh, dimana hal ini sangat diperlukan pada tahap perancangan.

b. Data-data subyektif yang berkaitan dengan perasaan atau kondisi tubuh seseorang pada saat berada di kamar RuKost yang bersangkutan akan diolah untuk mengetahui bagaimana kondisi nyata yang dirasakan penghuni selama berada dalam kamar. Subyektifitas ini berupa keluhan-keluhan sakit atau kaku diotot pada bagian tubuh tertentu dengan kondisi yang ada dan langkah-langkah analisis subyektifitasnya.

Metode pengambilan obyek sebagai sampel penelitian adalah purposif sampling, yaitu pengambilan sampel dengan tujuan tertentu. Selanjutnya sampel dalam penelitian ini disebut sebagai kasus. Analisis yang akan dilakukan adalah analisis deskriptif, berupa tabel frekuensi. Analisis ini juga akan digunakan untuk mengetahui tingkatan atribut yang paling berperan dalam pengambilan keputusan untuk merancang desain Rukost sesuai dengan kebutuhan yaitu nyaman dan ergonomis. Metode deskriptif bertujuan untuk mendapatkan gambaran atau deskripsi tentang suatu permasalahan yang akan diselesaikan. Lokasi penelitian terletak di Kabupaten Karawang Barat, Jawa Barat. Karawang dijadikan lokasi penelitian karena perkembangan industry di daerah tersebut sangat pesat yaitu dengan adanya kawasan industri KIIC, Suryacipta dan lain sebagainya. Lingkup materi penelitian meliputi materi fisik dan nonfisik. Materi fisik didapatkan berdasarkan pengamatan dan pengukuran. Sedangkan materi non fisik didapatkan dari hasil wawancara. Obyek penelitian adalah RuKost dengan luas kamar $9 \mathrm{~m} 2$.

\section{Diagram Alir Penelitian Perancangan Desain Kamar Kost}

Selanjutnya gambar 3 berikut adalah menjelaskan diagram alir keseluruhan yang dilakukan dalam penelitian ini. 


\section{HASIL DAN PEMBAHASAN}

A. Hasil Pengukuran dan Perhitungan

Berikut ini adalah hasil pengukuran dan perhitungan postur tubuh rata-rata mahasiswa dan karyawan yang berada di kecamatan Sukaharja, Karawang Barat:

Tabel 1. Data Antropometri Pada Posisi Berdiri

\begin{tabular}{llll}
\hline No. & Data Antropometri & $\mathrm{cm}$ & $\begin{array}{l}\text { Simpangan } \\
\text { Baku }\end{array}$ \\
\hline 1 & Tinggi Badan & 170.6 & 2.1 \\
2 & Tinggi Bahu & 144 & 3.2 \\
3 & Tinggi Siku & 108.6 & 2.5 \\
4 & Tinggi Pinggang & 99 & 2.7 \\
5 & Tinggi Paha & 71 & 2.5 \\
6 & Lebar Bahu & 40 & 3.4 \\
7 & Lebar Pinggul & 32.4 & 2.8 \\
8 & Panjang Lengan & 78 & 2.7 \\
9 & Panjang Lengan & 42 & 2.1 \\
& Bawah & & \\
10 & Panjang Lengan Atas & 36 & 2.6 \\
11 & Panjang Depa & 182 & 3.5 \\
12 & Jangkauan Atas & 214 & 4.1 \\
13 & Lebar Tubuh & 40 & 2.1 \\
14 & Tebal Tubuh & 23.9 & 2,3 \\
15 & Tinggi Lutut & 48 & 2.2 \\
\hline \multicolumn{3}{l}{ Sumber: Kuesioner dan Pengolahan Data }
\end{tabular}




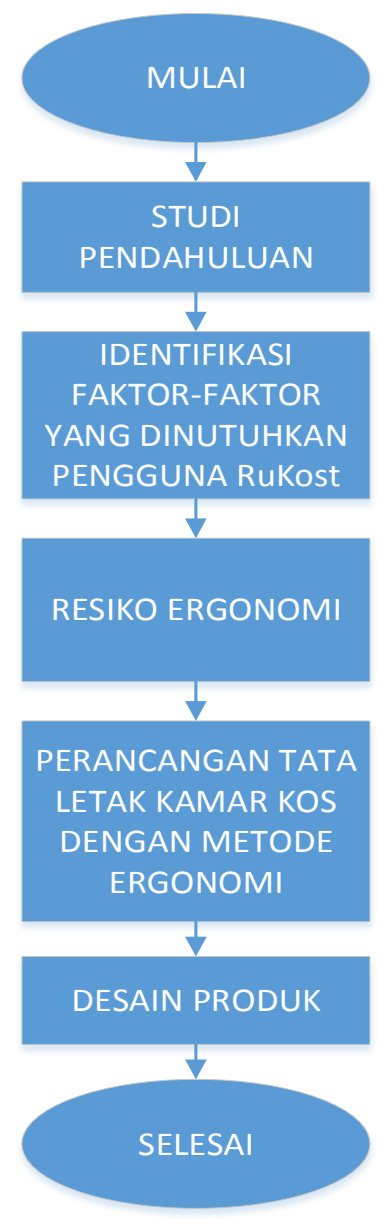

Gambar 3. Diagram Alir Penelitian

Tabel 2. Data Antropometri Kepala

\begin{tabular}{llll}
\hline No. & Data Antropometri & $\mathrm{cm}$ & $\begin{array}{l}\text { Simpangan } \\
\text { Baku }\end{array}$ \\
\hline 1 & Panjang Kepala & 15.8 & 2.1 \\
2 & Lebar Kepala & 15.1 & 1.8 \\
\hline \multicolumn{3}{l}{ Sumber: Kuesioner dan Pengolahan Data }
\end{tabular}

Selanjutnya dilakukan uji keseragaman data dan diperoleh data berada dalam rentang batas kendali atas dan batas kendali bawah. Selanjutnya dilakukan uji kecukupan data dan dengan menggunakan taraf keyakinan sebesar 95\% maka data dinyatakan cukup.Langkah berikutnya adalah menetapkan parameter data antropometri yang digunakan sebagai dasar dalam peletakan tempat tidur, lemari dan nakas pada kamar RuKost.

Tabel 3. Penyesuaian Desain Tempat Tidur Kamar RuKost

\begin{tabular}{lll}
\hline Uraian & Parameter $(\mathrm{cm})$ & Keterangan \\
\hline Segmen Tubuh 1 & 32.1 & Bahu-Kepala \\
Segmen Tubuh 2 & 53.0 & Pinggang-Bahu \\
Segmen Tubuh 3 & 31.7 & Pangkal Paha-Pinggang \\
Segmen Tubuh 4 & 29.0 & Lutut-Pangkal Paha \\
Segmen Tubuh 5 & 55.1 & Telapak kaki-Lutut \\
Lebar Tubuh & 40 & - \\
Tebal & 23.9 & - \\
\hline
\end{tabular}




\section{B. Desain Tata Letak Fasilitas Kamar}

Dengan mempertimbangkan kelonggaran, dimensi bahan yang digunakan dan faktor fungsional lainnya, maka didapat rancangan, sebagai berikut:

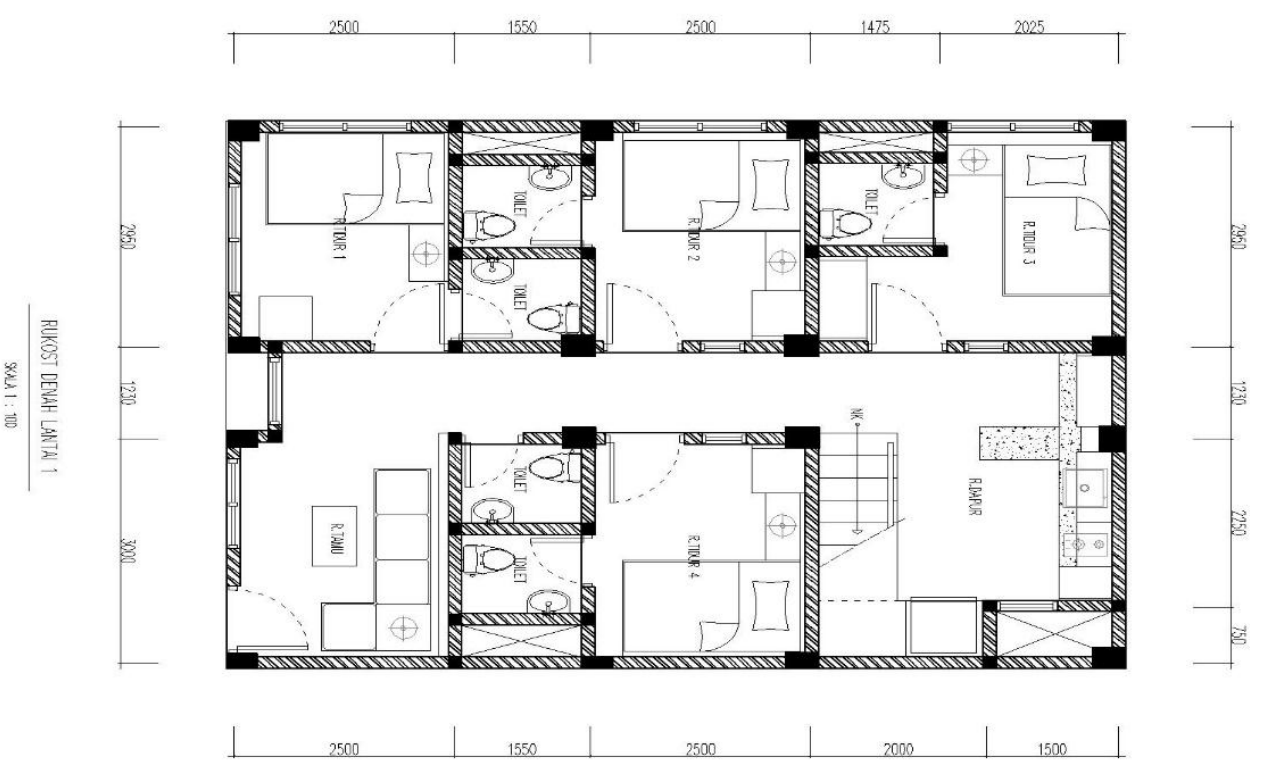

Gambar 4. Tataletak Fasilitas pada RuKost lantai 2
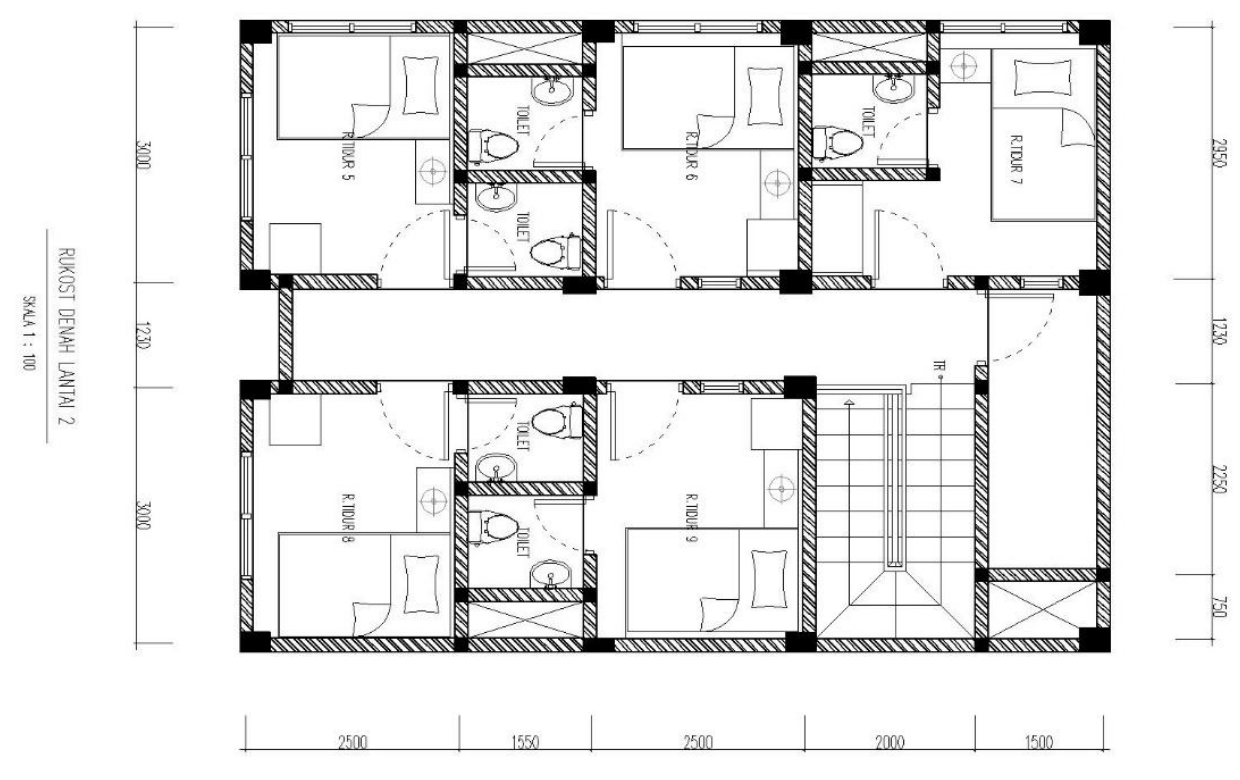

Gambar 5. Tataletak Fasilitas pada RuKost lantai 2 
Gambar diatas merupakan rancangan yang sudah dibuat berdasarkan konsep ergonomi dan hasil dari kuesioner yang telah diisi oleh pengguna kos-kosan di daerah Karawang. Desain ini menjawab keinginan dari penghuni kos dan menghasilkan kamar kos yang nyaman sesuai dengan antropometri penghuni kos-kosan daerah Karawang.

\section{KESIMPULAN DAN SARAN}

\section{A. Kesimpulan}

Aspek yang perlu diperhatikan dalam perancangan produk yang ergonomis antara lain adalah kesesuaian antara ukuran dimensi tubuh penggunanya dengan spesifikasi produk yang akan dibuat. Hasil penelitian ini memberikan rekomendasi merekomendasikan ukuran antropometri yang dapat digunakan sebagai masukan perancangan tata letak fasilitas yang ergonomis bagi konsumen penduduk Indonesia yang bekerja dan melakukan kegiatan di Karawang Barat adalah tinggi tubuh posisi berdiri 170,6 cm, tinggi bahu $144 \mathrm{~cm}$, tinggi pinggang $99 \mathrm{~cm}$, tinggi paha $71 \mathrm{~cm}$, tinggi lutut $47 \mathrm{~cm}$ lebar bahu $40 \mathrm{~cm}$, tebal perut $23,9 \mathrm{~cm}$, dan berat badan $67 \mathrm{~kg}$. Ukuran yang diperoleh melalui pengukuran dan pengolahan data anthropometri dijadikan tolok ukur dalam menetapkan rancangan tataletak fasilitas kamar RuKost. Selanjutnya dilakukan penyesuaian dengan memperhatikan facktor kelonggaran maka penelitian ini merekomendasikan nilai parameter akhir setelah adanya penyesuaian, yaitu tinggi tubuh posisi berdiri $195 \mathrm{~cm}$, tinggi bahu $150 \mathrm{~cm}$, tinggi pinggang $115,5 \mathrm{~cm}$, tinggi paha $80,2 \mathrm{~cm}$, tinggi lutut 53,5,0 cm, lebar bahu $41 \mathrm{~cm}$, tebal perut $24 \mathrm{~cm}$, dan berat badan $67.5 \mathrm{~kg}$.

\section{B. Saran}

Perlu dilakukan penelitian lebih lanjut mengenai ukuran dan dimensi kamar RuKost yang ideal secara simultan baik dari sisi pengguna Rukost maupun investor.

\section{DAFTAR PUSTAKA}

[1] Anonim, The Ergonomic Seating Guide Handbook, Haworth, 2011.

[2] Barnes, R.M, Motion and Time Study, toronto : John Wiley \& Sons, 1980.

[3] Bridger, R.S, Introduction to Ergonomics, McGRAW-HILL, 1995.

[4] Carayon, et.al., Reducing Workload and Increasing Patient Safety Through Wprk and Workspace Design, 2003.

[5] Eko Nurmianto, Ergonomi, konsep dasar \& aplikasinya, Jakarta: Guna Widya, 1996.

[6] Ernest J. McCORMICK, Human Factors In Engineering And Design, Tata McGraw- Hill Publishing Company Limited, New Delhi, 1992.

[7] Frick, H dan Suskiyatno, B., Dasar-dasar Arsitektur Ekologis. Konsep Pembangunan Berkelanjutan dan Ramah Lingkungan, Yogyakarta: Kanisius, 2007.

[8] Iridiastadi, H dan Yassierli, Ergonomi Suatu Pengantar, Bandung: Remaja Rosdakarya, 2014.

[9] Leola Dewiyani, Analisa Pasar Usaha Kos-kosan di Daerah Karawang. Laporan Penelitian, 2016.

[10] Leola Dewiyani, Hubungan Antara kualitas Hunian Kos dengan Kepuasan Pelangga, Laporan Penelitian, 2017.

[11] Markkanen, Pia, Keselamatan dan Kesehatan Kerja di Indonesia, ILO: Jakarta, 2014.

[12] Nurmianto, E., Ergonomi Konsep dasar dan Aplikasi. Jakarta: PT. Guna Widya, 2014.

[13] Sritomo Wignjosoebroto, Ergonomi, Studi Gerak \& waktu, Jakarta: Guna widya, 2004.

[14] Sritomo Wignjosoebroto, Sri Gunani, A. Pawennari, Jurnal ERGC, Analisis Ergonomi Terhadap Rancangan Fasilitas Kerja Pada Stasiun Kerja Dibagian Skiving Dengan Antropometri Orang Indonesia ( Studi Kasus Di Pabrik Vulkanisir Ban ), 2012.

[15] Sudjana, Metoda Statistika, Bandung: Tarsito, 1989. 